ORIGINAL ARTICLE

\title{
Airway inflammation in aluminium potroom asthma
}

\section{T Sjåheim, T S Halstensen, M B Lund, Ø Biørtuft, P A Drabløs, D Malterud, J Kongerud}

Occup Environ Med 2004;61:779-785. doi: 10.1136/oem.2003.011627

See end of article for authors' affiliations

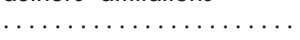

Correspondence to: Dr T Sjåheim, Department of Respiratory Medicine, National Hospital, 0027 Oslo, Norway; tonebs@ odont.vio.no

Accepted

14 February 2004

\begin{abstract}
Aims: To examine whether asthma induced by exposure to aluminium potroom emissions (potroom asthma) is associated with inflammatory changes in the airways.

Methods: Bronchial biopsy specimens from 20 asthmatic workers (8 non-smokers and 12 smokers), 15 healthy workers ( 8 non-smokers and 7 smokers), and 10 non-exposed controls (all non-smokers) were analysed. Immunohistofluorescent staining was performed to identify mucosal total leucocytes (CD45 leucocytes), neutrophils, and mast cells.

Results: Median RBM thickness was significantly increased in both asthmatic workers $(8.2 \mu \mathrm{m})$ and healthy workers $(7.4 \mu \mathrm{m})$ compared to non-exposed controls $(6.7 \mu \mathrm{m})$. Non-smoking asthmatic workers had significantly increased median density of lamina propria CD45 leucocytes (1519 cells $/ \mathrm{mm}^{2} v 660$ and 887 cells $/ \mathrm{mm}^{2}$ ) and eosinophils $\left(27\right.$ cells $/ \mathrm{mm}^{2} v 10$ and $\left.3 \mathrm{cells} / \mathrm{mm}^{2}\right)$ and significantly increased concentrations of exhaled NO (18.1 ppb $\vee 6.5$ and $5.1 \mathrm{ppb})$ compared to non-smoking healthy workers and non-exposed controls. Leucocyte counts and exhaled NO concentrations varied with smoking habits and fewer leucocytes were observed in asthmatic smokers than in non-smokers Asthmatic smokers had significantly increased numbers of eosinophils in lamina propria compared to non-exposed controls (10 v 3 cells $/ \mathrm{mm}^{2}$ ). Both eosinophilic and non-eosinophilic phenotypes of asthma were recognised in the potroom workers and signs of airway inflammation were also observed in healthy workers.

Conclusions: Airway inflammation is a central feature of potroom asthma and exposure to potroom emissions induces pathological alterations similar to those described in other types of asthma. Cigarette smoking seems to affect the underlying mechanisms involved in asthma, as the cellular composition of airway mucosa appears different in asthmatic smokers and non-smokers.
\end{abstract}

$\mathrm{T}$ he occurrence of work related asthmatic symptoms with airflow limitation in aluminium potroom workers, referred to as potroom asthma, has been documented in cross-sectional ${ }^{12}$ and longitudinal studies. ${ }^{13}$ Potroom asthma has been objectively confirmed by characteristic work related decreases in peak expiratory flow (PEF) measurements, ${ }^{45}$ and late asthmatic responses assessed by serial recording of forced expiratory volume in one second $\left(\mathrm{FEV}_{1}\right) .^{5}$ The reported incidence of potroom asthma varies from $0.06 \%$ to $4 \%$ of exposed workers per year. The variation in occurrence may partly be attributed to different definitions of the condition. ${ }^{1}$ The annual incidence in Norway has been about $1.5 \%$ in recent years and potroom asthma continues to represent an important health problem in Norwegian aluminium production.

Potroom workers are exposed to a complex mixture of particulates and gases. The respirable particles of the pot fume emissions are mainly composed of aluminium oxide, carbon dust, and cryolit (a fluorinated compound of sodium and aluminium), to which gases such as hydrogen fluoride and sulphur dioxide are absorbed. As the concentrations of several pollutants are correlated to each other, it has been difficult to identify the causal agent of potroom asthma, although a number of authors have suggested fluoride compounds to be the major candidate. ${ }^{167}$

Potroom asthma develops after a symptom-free period (latency) varying from weeks to years after first exposure and the most common clinical presentation is a late asthmatic reaction occurring a few hours after work. The pathogenetic mechanisms in potroom asthma remain unknown. Specific immunological reactions or an irritant effect have been suggested and there is evidence for the presence of both. ${ }^{8} 9$

A potential inflammatory response caused by exposure to potroom contaminants has been examined in a few studies; blood eosinophil counts increase during asthmatic attacks in potroom workers $^{10}$ and increased pre-employment blood eosinophil levels are related to the occurrence of potroom asthma. ${ }^{11}$ Although bronchial responsiveness is positively associated with potroom exposure, ${ }^{12}{ }^{13}$ the predicting value for potroom asthma is low. ${ }^{14}$ Healthy subjects exposed to hydrogen fluorides in concentrations similar to those regularly measured in aluminium smelters have increased numbers of lymphocytes in bronchoalveolar lavage fluid. ${ }^{15}$ In addition, both asthmatic and symptom-free potroom workers have increased concentrations of exhaled NO. ${ }^{16}$

These previous studies suggest that exposure to potroom contamination may induce airway inflammation and support the hypothesis that potroom asthma is an inflammatory disorder. However, examination of bronchial biopsy specimens, which is regarded as gold standard to assess airway inflammation, is lacking. We aimed to examine the presence of airway inflammation in asthmatic potroom workers by investigating bronchial biopsies and exhaled NO in subjects diagnosed as having occupational potroom asthma.

\section{METHODS}

\section{Subjects}

Potroom workers with occupational asthma (eight nonsmokers and 12 smokers), healthy potroom workers (eight non-smokers and seven smokers), and 10 healthy nonexposed controls (all non-smokers) were included. All asthmatic workers who had not left the plant were identified by the company physicians and were examined by the main investigator (TS) who confirmed the diagnosis of potroom asthma. From a total asthmatic population of 39 workers, 18 subjects were excluded for different reasons (lack of

Abbreviations: DIC, differential interference contrast; $\mathrm{FEV}_{1}$, forced expiratory volume in one second; FVC, forced vital capacity; NO, nitric oxide; RBM, reticular basement membrane; PEF, peak expiratory flow 
Main messages

- Workers with potroom asthma develop chronic bronchial inflammation.

- Non-smoking potroom asthmatics have similar inflammatory changes in airway mucosa as conventional asthma, shown by thickened RBM, increased leucocyte and eosinophil influx, and increased exhaled NO.

- Smoking potroom asthmatics have thickened RBM but lower leucocyte density than asthmatic non-smokers, suggesting an immunomodulating effect of tobacco smoking.

reversible airway obstruction, atopy, childhood asthma, exercise induced asthma, frequent airway infections, $\mathrm{FEV}_{1}$ $<70 \%$ of predicted value, cardiac disease).

of the 21 asthmatic workers fitting the inclusion criteria, only one was not included because he did not want to undergo a bronchoscopic examination.

The diagnosis of potroom asthma was made by confirming the diagnosis of bronchial asthma according to international guidelines $^{17}$ and by establishing a causal relation between asthma and the working environment, meeting the criteria for potroom asthma as previously defined. ${ }^{11}$ Serial monitoring of PEF was performed at work and away from work. The clinical criteria were: initially asymptomatic exposure period (latency), symptoms of airway obstruction (dyspnoea, wheezing, and cough), usually occurring several hours after exposure or during sleep, and improvement of the symptoms after absence from work for several days or longer. Reversible airway obstruction defined as $>15 \%$ increase in $\mathrm{FEV}_{1}$ after inhalation of $\beta_{2}$ agonist and diurnal PEF variability $>15 \%$ was documented in all asthmatic subjects. If work aggravation of underlying asthma was suspected, the subject was excluded. About half of the asthmatic workers were still working in the potrooms, and those relocated were working in non-polluted environments at the smelter. The relocated workers had persistent asthmatic symptoms, although all subjects reported gradual improvement of symptoms after withdrawal from exposure. The healthy workers and nonexposed controls had no symptoms from upper or lower airways and their lung function was normal. The 15 healthy workers were recruited by advertising the need for volunteers at one smelter employing about 440 pot operators. They were included successively as they responded and were comparable in age and smoking habits to the asthmatic workers. The 10 non-exposed controls were recruited from a normal healthy never-smoking population, responding to a request for volunteers at the University of Oslo. None of the participants had a history of allergy, familiar asthma, or childhood asthma and their total IgE levels were within the normal range. They had been free from respiratory tract infections for at least six weeks before investigations.

Table 1 shows the characteristics of the study population. Ex-smokers (quitting $>1$ year) and never-smokers were all classified as non-smokers. Five of the workers (two of the asthmatics and three of the healthy workers) were exsmokers. Median smoking load was 13 pack-years for the asthmatics and 17 pack-years for the healthy workers. The Regional Committee for Medical Research Ethics approved the study and informed written consent was obtained from each subject.

\section{Study design}

The workers were recruited from five Norwegian aluminium smelters during the period 1998-2002. Clinical examination

\section{Policy implications}

- Early diagnosis of potroom asthma and relocation is essential to prevent irreversible histopathological changes.

and recording of medical and occupational history was performed by a physician (TS); the subjects underwent spirometry, chest radiography, electrocardiography, blood tests, and measurement of exhaled NO the day before bronchoscopy with bronchial biopsy.

\section{Exposure}

In the Norwegian aluminium industry measurements of total airborne fluorides and dust are regularly performed from personal samplers. The mean levels of exposure are mostly far below the Norwegian threshold limit value (total fluorides $0.6 \mathrm{mg} / \mathrm{m}^{3}$ and total particulates $5 \mathrm{mg} / \mathrm{m}^{3}$ ), but peak exposures frequently occur. About $40 \%$ of the measurements for fluorides and $10 \%$ of the measurements for particulates are reported to exceed the hygienic limit values. In the present study, levels of exposure are not estimated for the individual worker, and only duration of exposure is recorded.

\section{Measurement of lung function and exhaled NO}

Spirometry was performed with a pneumotachograph (Vitalograph, Birmingham, UK) in accordance with the guidelines recommended by European Respiratory Society: ${ }^{18}$ the reference values of European Coal and Steel Community were used. ${ }^{18}$ Exhaled NO was measured by a chemiluminescence analyser (LR 2000, Logan Research, UK) at a sampling rate of $250 \mathrm{ml} / \mathrm{min}$ as previously described. ${ }^{16}$

\section{Bronchoscopy and processing of bronchial biopsy specimens}

Fibreoptic bronchoscopy and biopsy sampling was performed following the guidelines from the European Society of Pneumonology. ${ }^{19}$ All subjects were premedicated with atropine $0.6 \mathrm{mg}$ subcutaneously, $5 \mathrm{mg}$ diazepam orally, and alfentanil intravenously as needed (0-2 mg) for mild sedation and analgesic. Under local anaesthesia with lidocaine, a bronchoscope with working channel $2.8 \mathrm{~mm}$ (Pentax FB-19H or Olympus 20D IT) was used to obtain a maximum of six bronchial biopsy specimens from the second and third generation carinae of the right lung by a single use forceps (Microvasive 1267, Radial Jaw, Boston Scientific). The biopsy specimens were immediately embedded in Tissue-Tek Optimal Cutting Temperature Compound (Miles Laboratories, IN), snap frozen in isophentane precooled in liquid nitrogen, and stored at $-70^{\circ} \mathrm{C}$. Cryo sections were cut serially at $4 \mu \mathrm{m}$, dried overnight, and stored at $-20^{\circ} \mathrm{C}$ until use.

\section{Immunohistochemistry}

From a lower lobe biopsy, two sections of $100 \mu \mathrm{m}$ interval were prepared for immunohistofluorescence examination using antibodies (all Dako A/S, Denmark) against total common leucocytes CD45 (catalogue number M701), mast cell tryptase (M7052), and neutrophil elastase (M752). The primary antibodies were applied at optimal dilutions and incubated one hour at room temperature. The sections were prefixed for 10 minutes at $4{ }^{\circ} \mathrm{C}$ in $2 \%$ paraformaldehyde for CD45 staining and in 4\% paraformaldehyde for mast cell and neutrophil staining. Goat serum 5\% was then applied for 15 minutes to block unspecific binding sites. The secondary layer was biotinylated goat anti-mouse 
Table 1 Characteristics of the study population

\begin{tabular}{|c|c|c|c|c|c|}
\hline & \multicolumn{2}{|c|}{ Asthmatic workers $(n=20)$} & \multicolumn{2}{|c|}{ Healthy workers $(n=15)$} & \multirow{2}{*}{$\begin{array}{l}\text { Non-exposed controls } \\
(n=10) \\
\text { Non-smokers }(n=10)\end{array}$} \\
\hline & Non-smokers $(n=8)$ & Smokers ( $n=12$ ) & Non-smokers $(n=8)$ & Smokers $(n=7)$ & \\
\hline Age (years)* & $35(27-49)$ & $40(32-59)$ & $36(31-58)$ & $43(32-49)$ & $24(21-44)$ \\
\hline $\mathrm{FEV}_{1} \%$ pred* & $91(75-120)$ & $90(73-111)$ & $108(90-135)$ & $105(85-124)$ & $112(81-124)$ \\
\hline $\mathrm{FEV}_{1} / \mathrm{FVC} \% *$ & $78(61-82)$ & $67(59-79)$ & $80(71-87)$ & $75(71-84)$ & $81(74-90)$ \\
\hline Inhaled corticosteroids ( $\mathrm{n}$ ) & 1 & 3 & 0 & 0 & 0 \\
\hline Inhaled $\beta_{2}$ agonist (n) & 4 & 6 & 0 & 0 & 0 \\
\hline Duration of exposure (years)* & $14(4-28)$ & $11(8-25)$ & $14(13-25)$ & $19(13-24)$ & 0 \\
\hline Duration of symptoms (years)* & $10(1-22)$ & $11(1-18)$ & - & - & - \\
\hline Latency period (years) ${ }^{*}$ & $7(1-13)$ & $7(0.5-13)$ & - & - & - \\
\hline Relocated subjects (n) & 3 & 7 & - & - & - \\
\hline
\end{tabular}

*Data are presented as median (range).

$\mathrm{FEV}_{1}$, forced expiratory volume in 1 second; \% pred, percentage of predicted value; FVC, forced vital capacity.

immunoglobulin (Dako A/S) incubated for 1.5 hours followed by 0.5 hour incubation with Streptavidin Alexa 594 conjugate (Molecular Probes, Nederlands) mixed with DNA staining to visualise the nucleus (4,6-diamino-2phenylinodole (DAPI) Molecular Probes). Figure l shows an example of immunohistofluorescent staining of $\mathrm{CD}_{4} 5^{+}$ leucocytes. Methodological controls included sections stained without primary antibody and sections incubated with non-immune mouse immunoglobulin. The adjacent slides were stained with haematoxylin and eosin for examination of eosinophils.

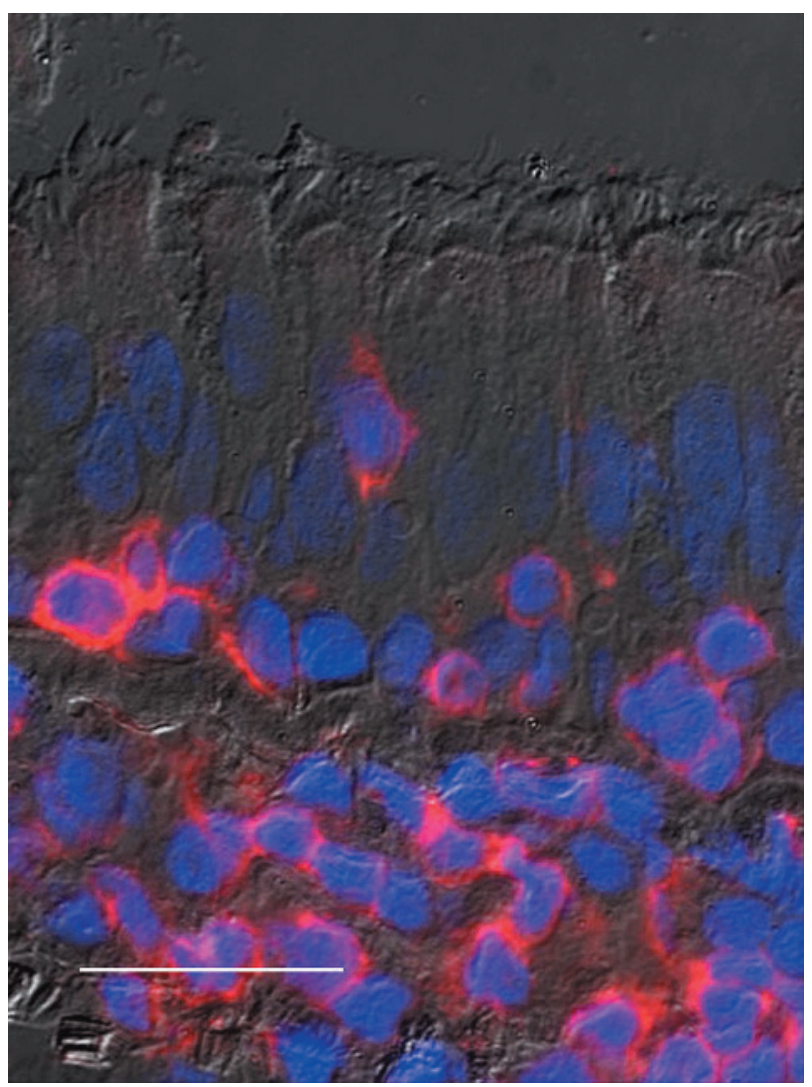

Figure 1 Immunofluorescent staining of $\mathrm{CD} 45^{+}$leucocytes (red) combined with 2,6-diamino-2-phenylinodole dihydrochloride (DAPI) to visualise the nucleus (blue) in a bronchial biopsy specimen from a nonsmoking subject with potroom asthma. Positively stained cells are seen in both the epithelium and lamina propria. Original magnification $\times 630$. Internal scale bar $=50 \mu \mathrm{m}$. (Pseudocolour multilayer image superimposed on differential interference contrast image)

\section{Quantitation of leucocytes}

All slides were analysed blind by one observer (TS) using a Zeiss Axioplane2 microscope at $630 \times$ magnification. Eosinophils were identified on haematoxylin and eosin stained slides examined by light microscopy in combination with differential interference contrast (DIC) microscopy. This method for identification of eosinophils has been shown to be more reliable in cryo sections than immunohistochemical labelling of eosinophil granule proteins. ${ }^{20}$ In cases of doubt, we additionally used the eosin fluorescence to localise the cell. Positively stained cells were counted in intact epithelium (defined as the presence of both basal and columnar cells) and in a tissue zone $114 \mu \mathrm{m}$ beneath the RBM, referred to as lamina propria. All available area was analysed. The final result, expressed as number of intraepithelial cells per millimetre of intact epithelium or number of cells per square millimetre of lamina propria, was calculated as the average of all the measurements performed of each section. The median length of intact epithelium examined in a subject was $5 \mathrm{~mm}$ (range $2-16 \mathrm{~mm}$ ) and the median area of lamina propria examined was $0.87 \mathrm{~mm}^{2}$ (range $0.36-2.24 \mathrm{~mm}^{2}$ ), corresponding to a basement membrane length of $6.2 \mathrm{~mm} \mathrm{(2.4-}$ $16.0 \mathrm{~mm})$, as recommended. ${ }^{21}$

\section{Measurements of RBM}

By use of DIC microscopy combined with light microscopy, a digital captured high power image was used to measure the distance from the base of the bronchial epithelium to the outer limit of the RBM by AnalySIS Soft Imaging System, as illustrated in fig 2. Only perpendicular cut sections were examined and a median of 68 measurements (range 37-161) were performed on each section at approximately $20 \mu \mathrm{m}$ intervals, as recommended. ${ }^{21}$

\section{Epithelial integrity}

The degree of epithelial damage was expressed as epithelial integrity, defined as the length of basal membrane covered with intact epithelium divided by the total length of the membrane. By light microscopy examination (haematoxylin and eosin stained slides and $630 \times$ magnification), a test grid (eyepiece reticule) was superimposed on the section, and the length of basal membrane with and without intact epithelium was recorded. A median of 31 grids were analysed for each subject, corresponding to a median length of basement membrane of $6.2 \mathrm{~mm}$.

\section{Statistics}

Results are presented as median (range) values. Differences between two groups were compared by the Mann-Whitney U test and correlation coefficients were calculated using Spearman's rank method. To control for potential confounders 


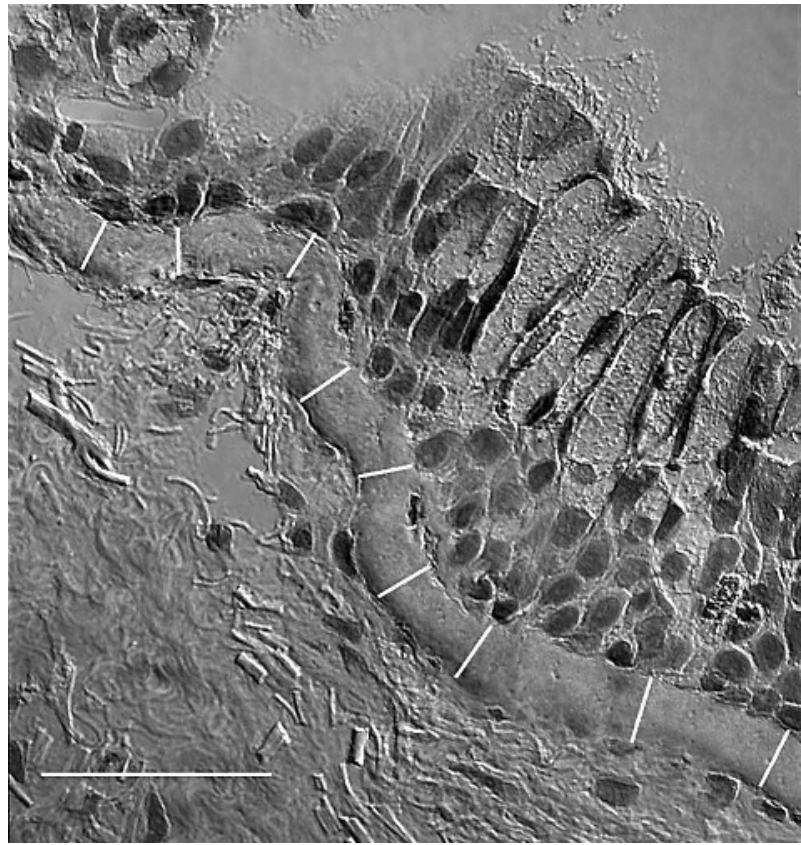

Figure 2 Examination of reticular basement membrane thickness performed on a haematoxylin and eosin stained slide combined with differential interference microscopy in a bronchial biopsy specimen from a patient with potroom asthma. Measurements are shown as white lines perpendicular to the reticular basement membrane. Original magnification $\times 630$. Internal scale bar $=50 \mu \mathrm{m}$.

(age and smoking habits), analysis of variance was performed for all results. A p value $<0.05$ was regarded as significant.

\section{RESULTS}

Leucocyte density in lamina propria, RBM thickness, epithelial integrity, and exhaled NO concentrations are shown in table 2 and the variables are shown as individual scatter plots in fig 3. The results varied with smoking habits and are presented for non-smokers and smokers separately. The nonexposed control group was younger than the other two groups, and the results were controlled for age. The only outcome parameter that varied with age was neutrophils, and a reduction in lamina propria neutrophils was seen with increasing age for all groups $(\mathrm{p}=0.01)$.

\section{Leucocyte density in lamina propria}

Asthmatic non-smokers had significantly higher density of $\mathrm{CD} 5^{+}$leucocytes (fig 3A) and eosinophils (fig 3B) compared to both non-smoking healthy workers and non-exposed controls (table 2). In contrast, a rather low density of leucocytes was observed in asthmatic smokers, in whom the densities of $\mathrm{CD}_{4} 5^{+}$leucocytes, eosinophils, and neutrophils were significantly reduced compared to asthmatic nonsmokers $(\mathrm{p}<0.001, \mathrm{p}=0.05$, and $\mathrm{p}=0.04$ respectively). The difference in mast cells did not reach the level of significance. Healthy workers (both non-smoking and smoking subgroup) had a significantly increased density of eosinophils compared to non-exposed controls $(p=0.04$ and $\mathrm{p}=0.01$ ).

Classifying subjects with eosinophil density above the upper range seen in non-exposed controls $\left(0-15\right.$ cells $\left./ \mathrm{mm}^{2}\right)$ as eosinophil(+), $50 \%$ of the asthmatics and $40 \%$ of the healthy workers were eosinophil(+) subjects. This cut-off value coincides with two standard deviations of the mean value in non-exposed controls.

\section{Intraepithelial cell counts}

The number of intraepithelial $\mathrm{CD}_{4} 5^{+}$leucocytes was significantly increased in both asthmatic ( 22 cells/mm epithelium) and healthy smokers (35 cells/mm epithelium) compared to the non-smoking groups. Within the nonsmoking groups there were no difference (varying from 8 to 11 cells/mm epithelium). Intraepithelial mast cells were significantly increased in asthmatic non-smokers compared to non-exposed controls ( $0.9 \vee 0.2$ cells $/ \mathrm{mm}$ epithelium, $\mathrm{p}=0.03)$.

\section{RBM}

RBM thickness did not vary with smoking habits. The RBM was significantly thickened in both asthmatics (median $8.2 \mu \mathrm{m}$, range $5.9-12.5 \mu \mathrm{m}$ ) and healthy workers (median $7.4 \mu \mathrm{m}$, range 5.6-9.0 $\mu \mathrm{m}$ ) compared to non-exposed controls (median $6.7 \mu \mathrm{m}$, range $6.0-7.6 \mu \mathrm{m})(\mathrm{p}=0.002$ and $\mathrm{p}=0.04$ respectively, fig 3C). The difference in RBM thickness between asthmatic and healthy workers was $0.8 \mu \mathrm{m}$ $(\mathrm{p}=0.055)$.

\section{Epithelial integrity}

In non-smokers, we found no significant difference in epithelial integrity between asthmatics and controls (table 2). Epithelial integrity was significantly increased in asthmatic smokers compared to asthmatic non-smokers $(p=0.03)$, but no difference was found between asthmatic

Table 2 Leucocyte density in lamina propria, reticular basement membrane thickness, epithelial integrity, and exhaled nitric oxide*

\begin{tabular}{|c|c|c|c|c|c|}
\hline & \multicolumn{2}{|c|}{ Asthmatic workers $(n=20)$} & \multicolumn{2}{|c|}{ Healthy workers $(n=15)$} & \multirow{2}{*}{$\begin{array}{l}\text { Non-exposed controls } \\
(n=10) \\
\text { Non-smokers }(n=10)\end{array}$} \\
\hline & Non-smokers $(n=8)$ & Smokers $(n=12)$ & Non-smokers $(n=8)$ & Smokers $(n=7)$ & \\
\hline $\begin{array}{l}\text { CD45 leucocytes } \\
\text { Eosinophils } \\
\text { Mast cells } \\
\text { Neutrophils } \\
\text { RBM ( } \mu \mathrm{m}) \\
\text { Epithelial integrity (\%) } \\
\text { Exhaled NO (ppb) }\end{array}$ & $\begin{array}{l}1519(720-1917) \dagger \S \\
27(6-164) \dagger \S \\
116(66-161) \\
83(46-162) \S \\
8.2(7.5-10.2) \dagger \\
52(0-90) \S \\
18.1(6.3-91.1) \dagger \S\end{array}$ & $\begin{array}{l}675(452-914) \\
10(0-41) \\
78(29-141) \\
42(13-93) \\
8.0(5.9-12.5) \\
70(51-96) \\
4.4(1.2-80.0)\end{array}$ & $\begin{array}{l}660(415-1289) \\
10(3-24) \ddagger \\
93(43-169) \\
45(18-110) \\
7.2(5.6-8.7) \\
41(18-93) \\
6.5(3.1-22.8)\end{array}$ & $\begin{array}{l}897(503-1871) \\
33(2-193) \\
105(34-199) \\
56(23-98) \\
7.6(6.8-9.0) \ddagger \\
67(38-97) \\
4.1(1.6-20.3)\end{array}$ & $\begin{array}{l}887(566-1595) \\
3(0-15) \\
89(30-118) \\
84(29-175) \\
6.7(6.0-7.6) \\
42(13-70) \\
5.1(3.5-8.4)\end{array}$ \\
\hline \multicolumn{6}{|c|}{$\begin{array}{l}\text { RBM, reticular basement membrane; ppb, parts per billion. } \\
\text { Cell counts are expressed as cells } / \mathrm{mm}^{2} \text {. } \\
{ }^{*} \text { Data are expressed as median (range). } \\
\dagger p \leqslant 0.05 v \text { non-smoking healthy workers and non-exposed controls. } \\
\neq p<0.05 v \text { non-exposed controls. } \\
\S p<0.05 v \text { smoking asthmatic workers. }\end{array}$} \\
\hline
\end{tabular}



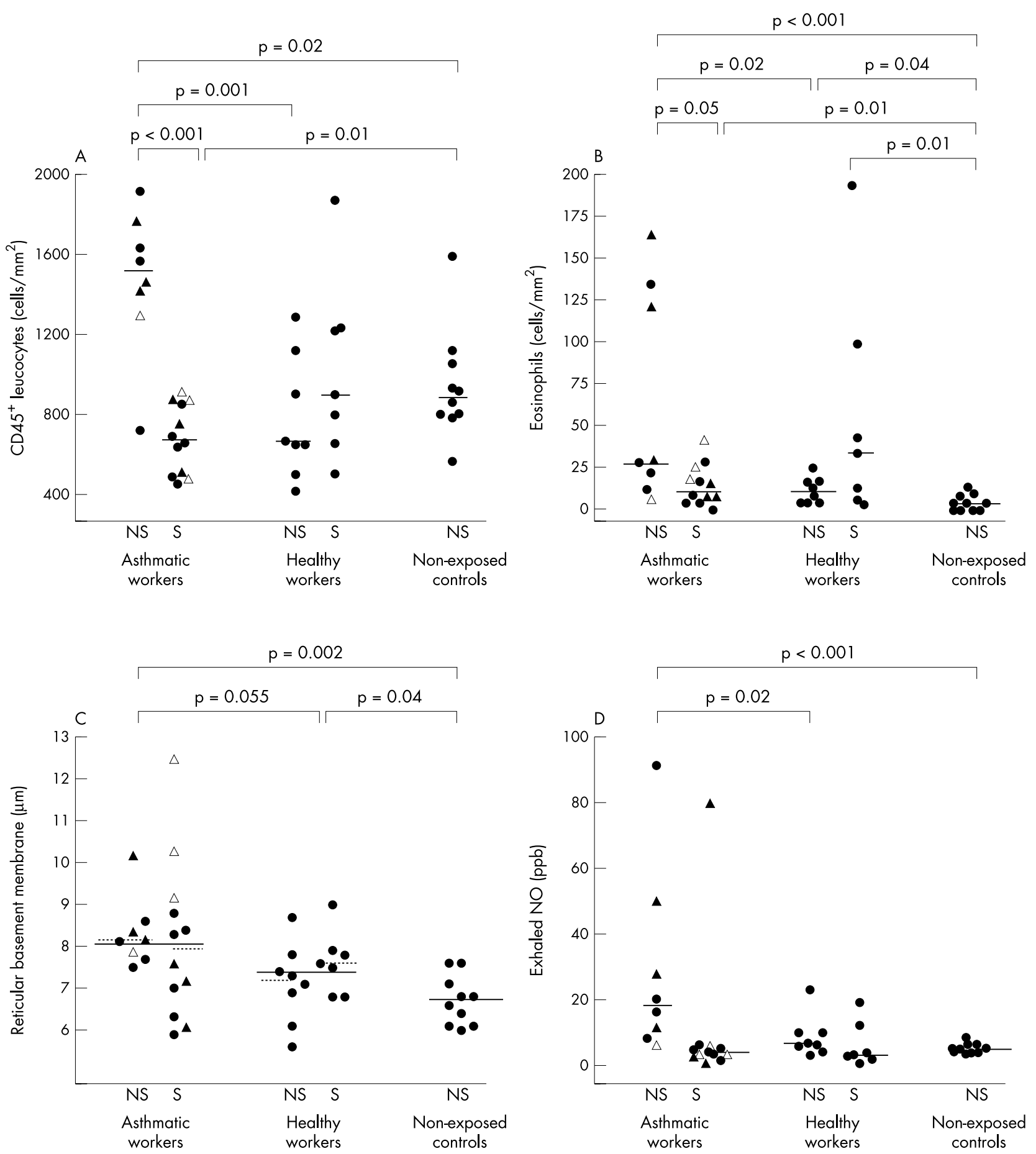

Figure 3 Individual leucocyte counts in lamina propria (A: CD45 leucocytes; B: eosinophils), RBM thickness (C), and exhaled nitric oxide (D) in nonsmoking (NS) and smoking (S) asthmatic potroom workers, healthy potroom workers, and non-exposed controls. Data are expressed as number of cells per square millimetre of tissue. Horizontal bars represent median values. Dark triangles indicate treatment with $\beta_{2}$ agonists and open triangles indicate treatment with inhaled corticosteroids.

smokers and the smoking healthy workers. In the damaged area, the ciliated epithelial cells were often absent while the layer of cuboidal basal cells was intact.

\section{Exhaled NO}

In non-smoking subjects, the concentrations of exhaled NO were significantly higher in asthmatic workers than in both healthy workers and non-exposed controls (fig 3D). Exhaled NO was, as expected, low in smokers, and NO values in asthmatic smokers did not differ from those in control smokers. In non-smoking asthmatic workers, exhaled NO correlated to the density of lamina propria $\mathrm{CD} 45^{+}$leucocytes $(r=0.81, \mathrm{p}=0.02)$ and eosinophils $(r=0.79, \mathrm{p}=0.02)$.

\section{Exposure and outcome variables}

We found no association between number of years employed in the potrooms and any of the outcome parameters. There was no difference between asthmatic workers who were still exposed in the potrooms and those who were relocated to non-polluted working environments. 


\section{DISCUSSION}

This study reveals the presence of airway inflammation in subjects with potroom asthma, shown by significantly increased density of lamina propria $\mathrm{CD} 45^{+}$leucocytes and eosinophils, significantly increased numbers of intraepithelial mast cells, thickening of RBM, and increased exhaled NO in asthmatic non-smokers. In addition, a subclinical inflammation, shown by significantly increased lamina propria eosinophils and RBM thickening, was observed in healthy potroom workers when compared to non-exposed controls.

Similar results have been reported in earlier studies of nonsmokers with occupational asthma induced by low-molecular weight compounds such as isocyanates ${ }^{22}$ and plicatic acid in western red cedar ${ }^{23}$ as well as non-occupational asthma. ${ }^{24} 25$ Earlier studies in aluminium smelters indicate that eosinophils contribute to the pathophysiology of potroom asthma and we could confirm the presence of airway mucosal eosinophilia. However, about half of the asthmatic workers had eosinophil counts in the range observed for non-exposed controls. These findings are in line with the increasing recognition of non-eosinophilic forms of asthma, ${ }^{26}{ }^{27}$ also observed in other forms of occupational asthma. ${ }^{28}$ Our data did not support the hypothesis that non-eosinophilic asthma is a neutrophil mediated inflammation ${ }^{27} 29$ as we found no difference in neutrophil density between eosinophilic and non-eosinophilic groups. Neutrophil involvement in the pathogenesis of occupational asthma has been documented in asthma induced by isocyanates ${ }^{30}$ and grain-dust, ${ }^{31}$ but in contrast to these studies, we were unable to show increased density of neutrophils in the airway wall in our asthmatics.

The number of intraepithelial mast cells was significantly increased in non-smoking asthmatics, but no difference in lamina propria mast cells was found between the groups. This is somewhat surprising, since mast cells are regarded as an important effectors cell of the asthmatic inflammation. ${ }^{24}$ However, in previous studies the number of mast cells tended to vary. ${ }^{32-34}$ Our results are in line with a study by Saetta et al who found mast cells numbers to be increased only in the epithelium. ${ }^{22}$ In another study, increased numbers of mast cells were found in both the epithelium and lamina propria in subjects who developed asthma after a short time (median 2 years) of exposure to isocyanates..$^{33}$ The latency period in our study was longer (median 7 years, range 0.5-13 years), suggesting that mast cells might be associated with individual susceptibility to exposure.

Loss of epithelial integrity is commonly found in asthmatics, although this finding is inconsistently reported..$^{35} 36$ Our results in non-smoking asthmatics agree with previous studies. ${ }^{36}$ We found, as have other researchers ${ }^{37}$ that it is difficult to obtain biopsy samples from normal subjects. Hence, we hypothesise that mechanical biopsy induced damage to the bronchial epithelium is more likely to occur in healthy subjects and can explain the higher epithelial damage found in our controls. Thus, in vivo damage can possibly not be distinguished from biopsy induced, artifactual damage in our study. We also found that biopsy specimens were most easily taken from smokers.

Wide variations exist in the reported ranges of RBM thickness, in both asthmatic and control airways, ${ }^{38}$ and may partly be due to different tissue handling and measurement techniques. Compared to a study with similar biopsy processing, ${ }^{39} \mathrm{RBM}$ in the present study appear thinner in the asthmatics and thicker in the controls. Although the difference between the groups appears to be smaller, it is significant. We have performed a higher number of measurements than in most other studies and found that the RBM thickness shows great variations within one section, even in perpendicular cut areas.
The finding of increased exhaled NO concentrations in non-smoking workers with potroom asthma is in accordance with a preceding study by Lund and colleagues. ${ }^{16}$ In addition we found a positive correlation between exhaled NO concentrations and the density of lamina propria $\mathrm{CD} 45^{+}$ leucocytes and eosinophils in subjects with potroom asthma. Similar correlations were not observed in the healthy workers.

The observed significant increase in some inflammatory markers in healthy potroom workers is an interesting finding. Compared to non-exposed controls, the healthy potroom workers had a higher density of lamina propria eosinophils and thicker RBM, and their exhaled NO tended to be higher. These findings suggest that exposure to pollutants in aluminium smelters may affect the bronchial mucosa and induce a subclinical airway inflammation, even in healthy asymptomatic workers.

An unexpected finding was the impact of smoking in asthmatics. Asthmatic smokers had lower leucocyte density than asthmatic non-smokers. A higher proportion of asthmatic smokers were treated with inhaled steroids (3/12 of asthmatic smokers $v \quad 1 / 8$ of asthmatic non-smokers). However, the difference in leucocyte density and exhaled NO values between the two asthma groups cannot be explained by anti-inflammatory treatment, as excluding the four subjects on inhaled corticosteroids from our analyses did not change the overall results.

A misclassification of asthma also seems unlikely. The smokers who were diagnosed as asthmatics had symptoms, PEF measurements, and reversibility consistent with potroom asthma and not chronic obstructive lung disease, and their median $\mathrm{FEV}_{\mathrm{l}}$ was comparable to that in non-smoking asthmatics ( $90 \% \vee 91 \%$ of predicted value). Two of the asthmatic workers and three of the healthy workers were exsmokers. (The asthmatics had smoked respectively 8 and 20 pack-years and had stopped smoking 3 and 13 years ago. The healthy workers had smoked 2, 5, and 11 pack-years and had stopped respectively 14, 15, and 6 years ago.) No studies are available to clarify a potential effect of cigarette smoking on inflammatory parameters in the airways of previous smokers. Excluding the five ex-smokers from the analyses did not change the main results, but the sample size might be too small to show a hangover effect of smoking.

Studies of asthmatic inflammation in humans have been limited to non-smokers, and to our knowledge there is no published biopsy study including asthmatic smokers.

Hence, an immunomodulating effect of smoking on airway mucosa in asthmatics has not previously been shown, but recent publications from peripheral blood ${ }^{40}$ and induced sputum $^{41}$ of smoking asthmatics support our data. In agreement with other studies showing smoking to induce an inflammatory airway reaction in non-asthmatics, ${ }^{42}$ the smoking healthy workers tended to have higher leucocyte density compared to non-smoking healthy workers.

Smoking in itself may be immunomodulating rather than proinflammatory. This is supported by several human and animal studies.$^{43}$ Nicotine was recently shown to have a direct inhibitory effect on the production of proinflammatory mediators by stimulating the nicotinic acetylcholine receptor. ${ }^{44}$ Moreover, in a recent study a smoke induced reduction in the number of dendritic cells in the murine lung was reported. ${ }^{45}$ The finding that smoke exposure influences the antigen presenting cells may have profound effects on immune responsiveness.

According to this, it is likely that the relatively low number of leucocytes in the airway wall found in our asthmatic smokers was induced by smoking and not by occupational exposure or interaction effects. However, at present we have no explanation for why smoking seems to have a 
pro-inflammatory effect in non-asthmatics but an antiinflammatory effect in asthmatics.

In conclusion, in non-smoking workers with potroom asthma characteristic immunopathological features of asthma such as inflammatory cell infiltrate, thickening of RBM, and increased levels of exhaled NO were shown. In asthmatic smokers, only thickening of RBM was observed, suggesting a different pathophysiological process for potroom asthma in smokers than in non-smokers. In healthy workers, exposure to pot fume emissions may induce a subclinical airway inflammation.

\section{ACKNOWLEDGEMENTS}

We thank the aluminium potroom workers for participating in the study, and Professor Thore Egeland, University of Oslo, for statistical support.

\section{Authors' affiliations}

T Sjåheim, M B Lund, Ø Bjørtuft, J Kongerud, Department of Respiratory Medicine, National Hospital, University of Oslo, Norway

T S Halstensen, Department of Oral Biology, University of Oslo, Norway

P A Drabløs, Health Department, Hydro Aluminium Karmøy, Norway

D Malterud, Health Department, Elkem Aluminium Lista, Norway

Funding: This study was supported by grants from the Norwegian Research Council, University of Oslo, and Nordic Aluminium Industry's Secretariat for Health, Environment and Safety (AMS)

\section{REFERENCES}

1 Abramson MJ, Wlodarczyk JH, Saunders NA, et al. Does aluminium smelting cause lung disease? Am Rev Respir Dis 1989;139:1042-57.

2 Kongerud J, Gronnesby JK, Magnus P. Respiratory symptoms and lung function of aluminium potroom workers. Scand J Work Environ Health 1990;16:270-7.

3 Kongerud J, Samuelsen SO. A longitudinal study of respiratory symptoms in aluminium potroom workers. Am Rev Respir Dis 1991;144:10-16.

4 Kongerud J, Soyseth V, Burge S. Serial measurements of peak expiratory flow and responsiveness to methacholine in the diagnosis of aluminium potroom asthma. Thorax 1992;47:292-7.

5 Desjardins A, Bergeron JP, Ghezzo H, et al. Aluminium potroom asthma confirmed by monitoring of forced expiratory volume in one second. Am J Respir Crit Care Med 1994;150:1714-17.

6 Soyseth V, Kongerud J. Prevalence of respiratory disorders among aluminium potroom workers in relation to exposure to fluoride. $\mathrm{Br} \mathrm{J}$ Ind Med 1992;49: 125-30

7 Steinegger AF, Schlatter C. Evaluation of fluoride exposure in aluminium smelters: state of the art. Med Lav 1992;83:489-98.

8 Saric M, Zuskin E, Gomzi M. Bronchoconstriction in potroom workers. Br J Ind Med 1979:36:211-15.

9 Chan-Yeung M, Lam S. Occupational asthma. Am Rev Respir Dis 1986; 133:686-703

10 Midttun $\mathrm{O}$. Bronchial asthma in the aluminium industry. Acta Allergol 1960;15:208-21.

11 Sorgdrager B, Pal TM, de Looff AJ, et al. Occupational asthma in aluminium potroom workers related to pre-employment eosinophil count. Eur Respir J 1995;8:1520-4.

12 Soyseth V, Kongerud J, Ekstrand J, et al. Relation between exposure to fluoride and bronchial responsiveness in aluminium potroom workers with work-related asthma-like symptoms. Thorax 1994;49:984-9.

13 Soyseth V, Kongerud J, Aalen OO, ef al. Bronchial responsiveness decreases in relocated aluminium potroom workers compared with workers who continue their potroom exposure. Int Arch Occup Environ Health 1995:67:53-7.

14 Kongerud J, Soyseth V. Methacholine responsiveness, respiratory symptoms and pulmonary function in aluminium potroom workers. Eur Respir $J$ 1991;4:159-66.

15 Lund K, Refsnes M, Sandstrom T, et al. Increased CD3 positive cells in bronchoalveolar lavage fluid after hydrogen fluoride inhalation. Scand J Work Environ Health 1999;25:326-34.

16 Lund MB, Oksne Pl, Hamre R, et al. Increased nitric oxide in exhaled air: an early marker of asthma in non-smoking aluminium potroom workers? Occup Environ Med 2000:57:274-8.

17 Anon. International consensus report on diagnosis and treatment of asthma. National Heart, Lung, and Blood Institute, National Institutes of Health.
Bethesda, Maryland 20892. Publication no. 92-3091, March 1992. Eur Respir J 1992;5:601-41.

18 Quanjer PH, Tammeling GJ, Cotes JE, et al. Lung volumes and forced ventilatory flows. Report Working Party Standardization of Lung Function Tests, European Community for Steel and Coal. Official Statement of the European Respiratory Society. Eur Respir J Suppl 1993;16:5-40.

19 Anon. Investigative use of bronchoscopy, lavage and bronchial biopsies in asthma and other airways diseases. Workshop summary and guidelines. Eur Respir J 1992;5:115-21.

20 Jahnsen FL, Haraldsen G, Rugtveit J, et al. Differential interference contrast microscopy combined with immunofluorescence: a new method to phenotype eosinophils in situ. J Immunol Methods 1994;173:77-91.

21 Sullivan P, Stephens D, Ansari T, et al. Variation in the measurements of basement membrane thickness and inflammatory cell number in bronchial biopsies. Eur Respir J 1998;12:811-15.

22 Saetta M, Di Stefano A, Maestrelli P, et al. Airway mucosal inflammation in occupational asthma induced by toluene diisocyanate. Am Rev Respir Dis 1992;145:160-8.

23 Frew AJ, Chan $\mathrm{H}$, Lam S, et al. Bronchial inflammation in occupational asthma due to western red cedar. Am J Respir Crit Care Med 1995; 151:340-4.

24 Busse WW, Lemanske RF, Jr Asthma. N Engl J Med 2001;344:350-62.

25 Kharitonov SA, Yates D, Robbins RA, et al. Increased nitric oxide in exhaled air of asthmatic patients. Lancet 1994;343:133-5.

26 Wenzel SE, Schwartz LB, Langmack EL, et al. Evidence that severe asthma can be divided pathologically into two inflammatory subtypes with distinct physiologic and clinical characteristics. Am J Respir Crit Care Med 1999; 160:1001-8.

27 Douwes J, Gibson P, Pekkanen J, et al. Non-eosinophilic asthma: importance and possible mechanisms. Thorax 2002;57:643-8.

28 Anees W, Huggins V, Pavord ID, et al. Occupational asthma due to low molecular weight agents: eosinophilic and non-eosinophilic variants. Thorax 2002;57:231-6

29 Gibson PG, Simpson JL, Saltos N. Heterogeneity of airway inflammation in persistent asthma: evidence of neutrophilic inflammation and increased sputum interleukin-8. Chest 2001;119:1329-36.

30 Park HS, Hwang SC, Nahm DH, et al. Immunohistochemical characterization of the cellular infiltrate in airway mucosa of toluene diisocyanate (TDI)-induced asthma: comparison with allergic asthma. Journal of Korean Medical Science 1998; 13:21-6

31 Park HS, Jung KS, Hwang SC, et al. Neutrophil infiltration and release of IL-8 in airway mucosa from subjects with grain dust-induced occupational asthma. Clin Exp Allergy 1998;28:724-30.

32 Diukanovi R, Wilson JW, Britten KM, et al. Quantitation of mast cells and eosinophils in the bronchial mucosa of symptomatic atopic asthmatics and healthy control subjects using immunohistochemistry. Am Rev Respir Dis 1990; 142:863-71.

33 Di Stefano A, Saetta M, Maestrelli P, et al. Mast cells in the airway mucosa and rapid development of occupational asthma induced by toluene diisocyanate. Am Rev Respir Dis 1993;147:1005-9.

34 Saetta M, Maestrelli P, Di Stefano A, et al. Effect of cessation of exposure to toluene diisocyanate (TDI) on bronchial mucosa of subjects with TDI-induced asthma. Am Rev Respir Dis 1992;145:169-74.

35 Jeffery PK. Remodeling in asthma and chronic obstructive lung disease. Am J Respir Crit Care Med 2001;164:S28-38.

36 Boulet $\mathbf{L P}$, Laviolette $M$, Turcotte $H$, et al. Bronchial subepithelial fibrosis correlates with airway responsiveness to methacholine. Chest 1997; 1 12:45-52.

37 Ordonez C, Ferrando R, Hyde DM, et al. Epithelial desquamation in asthma: artifact or pathology? Am J Respir Crit Care Med 2000;162:2324-9.

38 Wilson JW, Li X. The measurement of reticular basement membrane and submucosal collagen in the asthmatic airway. Clin Exp Allergy 1997:27:363-71.

39 Van Den Toorn LM, Overbeek SE, De Jongste JC, et al. Airway inflammation is present during clinical remission of atopic asthma. Am J Respir Crit Care Med 2001;164:2107-13.

40 Sunyer J, Springer G, Jamieson B, et al. Effects of asthma on cell components in peripheral blood among smokers and non-smokers. Clin Exp Allergy 2003;33:1500-5.

41 Chalmers GW, MacLeod KJ, Thomson L, et al. Smoking and airway inflammation in patients with mild asthma. Chest 2001;120:1917-22.

42 Amin K, Ekeberg-Jansson A, Løfdahl C, et al. Relationship between inflammatory cells and structural changes in the lungs of asymptomatic and never smokers: a biopsy study. Thorax 2003;58:135-42.

43 Holt PG. Immune and inflammatory function in cigarette smokers. Thorax 1987;42:241-9

44 Wang H, Yu M, Ochani $M$, et al. Nicotinic acetylcholine receptor alpha7 subunit is an essential regulator of inflammation. Nature 2003:421:384-8.

45 Robbins CS, Dawe DE, Goncharova SI, et al. Cigarette smoke decreases pulmonary dendritic cells and impacts antiviral immune responsiveness. Am J Respir Cell Mol Biol 2004;30:202-11 